\title{
Development of Haematological Indices in Melanoma-bearing Liběchov Minipigs
}

\author{
M. SVOBODA ${ }^{1}$, K. EICHLEROVÁ ${ }^{1}$, V. HORÁK ${ }^{2}$, J. HRADECKÝ ${ }^{2}$ \\ ${ }^{1}$ Clinic of Pig Diseases, Faculty of Veterinary Medicine, University of Veterinary and Pharmaceutical Sciences, \\ Brno, Czech Republic \\ 2Institute of Animal Physiology and Genetics, Academy of Sciences of the Czech Republic, Liběchov, \\ Czech Republic
}

Received February 18, 2005

Accepted November 10, 2005

\begin{abstract}
Svoboda M., K. Eichlerová, V. Horák, J. Hradecký: Development of Haematological Indices in Melanoma-bearing Liběchov Minipigs. Acta Vet. Brno 2005, 74: 603-611.

The aim of the study was to investigate the development of haematological indices in the MeLiM strain of miniature pigs. MeLiM minipigs in group $\mathrm{M}$ were affected with hereditary malignant melanoma and received $100 \mathrm{mg} \mathrm{Fe}{ }^{3+}$ dextran i.m. on day 3 of age. Group $\mathrm{H}$ contained melanomafree MeLiM minipigs that were supplemented with iron as in group M. Melanoma-free MeLiM minipigs without iron supplementation till the week 5 of age were included in group A. Development of haematological indices in group $\mathrm{H}$ was compared to literature data from other breeds and strains of minipigs. Red blood cell indices in group A were found to be characteristic for hypochromic microcytary anaemia. Higher red blood cell counts were found in animals affected with melanoma (group M) on week 8 of age compared to group H. Pigs in group M showed also lower growth intensity compared to healthy animals (group $\mathrm{H}$ ).
\end{abstract}

Hereditary melanoma, MeLiM, haemoglobin, packed cell volume, iron

Melanoma (melanobastoma)-bearing Liběchov minipigs (MeLiM) were used in the study. The MeLiM strain of miniature pigs was created after 10 years of selective breeding of animals bearing cutaneus melanomas. Two strains of miniature pigs (Hormel and Göttingen) and several other breeds (Cornwall, Landrace, Vietnamese pig, Large White) participated at establishment of the MeLiM strain (Hruban et al. 2004). Main features of miniature pigs, i. e. small size and early sexual maturity are observed in the MeLiM strain. The sexual maturity is achieved at the age of 4 months. Small size of breeding herd resulted in a partial inbreeding of this miniature pig strain $(\mathrm{F}=0.30)$. This inbreeding neither decreased number of born piglets per litter nor brought any other negative effects (e.g. high postnatal mortality, morphological malformation) (Horák et al. 1999). However, it is probably responsible for severity of this cancer disease in the MeLiM strain. Malignant melanoma in this strain shows a hereditary occurrence. Primary cutaneous melanomas are mostly multiple and they show usually a tuberous nodular form. The primary skin tumours occur in dark-pigmented (black or rusty red) piglets as early as at birth or during the first 2 months of life. About half of all animals develop the tumours. Metastases are broadly disseminated in various organs and tissues. They are regularly found in the spleen, lymph nodes and lungs (Fortýn et al. 1994; Horák et al. 1999). In highly affected minipigs, metastases are found also in various parts of digestive tract, pancreas, liver, kidneys, thymus and other organs (Fortýn et al. 1998). No correlation between number and size of skin tumours on one side and extent of inner metastases on the other side has been found. Roughly one third of melanoma-bearing minipigs die due to melanoma progression (Horák et al. 1999). Numerous histopathological (Vincent-Naulleau et al. 2004), biochemical (Borovanský et al. 2003) and molecular-biological similarities (Pohlreich et al. 2001) with human melanoma were found. All these results suggest that the MeLiM minipigs are

Address for correspondence:

MVDr. Martin Svoboda, Ph.D.

University of Veterinary and Pharmaceutical Science

Palackého 1-3, 61242 Brno

Czech Republic
Phone: +420541562433

Fax: +4205748841

E-mail: svobodama@vfu.cz

http://www.vfu.cz/acta-vet/actavet.htm 
a suitable animal model for study of this cancer disease. Successful experimental therapy of malignant melanoma in the MeLiM minipigs was achieved by devitalization (ischaemization) technique (Fortýn et al. 1994; Horák et al. 1999).

The blood picture offers important information about animals' state. Animal breed (strain) and iron belong to important factors influencing the blood picture. The importance of iron supplementation is well known in commercial pig breeds. The piglet of these breeds is born with limited reserve of iron ( $50 \mathrm{mg} \mathrm{Fe}$ ) (Venn et al. 1947; Zi mmermann 1995). The daily requirement of iron during the first few weeks of life is around 7-10 mg) (Venn et al. 1947). However, the sow's milk provides the piglet with approximately $1 \mathrm{mg} F$ per day only (Csapó 1995; Kleinbeck and McGlone 1999). Without iron supplementation, suckling piglets develop anaemia during 10-14 days after birth (Framstad and Sjaastad 1991; Zimmermann 1995). The most common approach for prevention of iron deficiency anaemia in baby pigs is to inject $200 \mathrm{mg} \mathrm{Fe}^{3+}$ as iron-dextran on the $3^{\text {rd }}$ day of life (Carls s on et al. 1974; Y u et al. 2002). In minipigs, injection of $100 \mathrm{mg} \mathrm{Fe} \mathrm{F}^{3+}$ as iron dextran on the $3^{\text {rd }}$ day of life is recommended (Mandel and Trávníček 1982).

The following goals of our study were determined:

1. Evaluation of development of haematological indices in melanoma-free iron supplemented MeLiM minipigs (group $\mathrm{H}$ ).

2. Evaluation of development of haematological indices in melanoma-free MeLiM minipigs without supplementation with iron (group A).

3. Evaluation of development of haematological indices in iron-supplemented MeLiM minipigs with melanoma.

\section{Materials and Methods}

\section{Experimental design}

A total of 49 of MeLiM minipigs were used in the study. The piglets were individually tattooed with a number in the ear. They were divided into 3 groups. Group A (anaemic) had 11 melanoma-free minipigs. Piglets in this group did not receive any iron preparation till 5 weeks of age. At this age, theys were injected i.m. with $100 \mathrm{mg} \mathrm{Fe}^{3+}$ in the form of iron dextran (Ferridextran, Spofa, Czech Republic).

Group $\mathrm{H}$ (healthy) included 11 melanoma-free minipigs. They were injected i.m. with $100 \mathrm{mg} \mathrm{Fe}^{3+}$ in the form of iron dextran on the $3^{\text {rd }}$ day of life.

Group M (melanoma-bearing) had 27 minipigs with occurrence of primary cutaneus melanoma. They were injected i.m. with $100 \mathrm{mg} \mathrm{Fe}^{3+}$ in the form of iron dextran on the $3^{\text {rd }}$ day of life.

Piglets of all groups were weaned at the age of 9 weeks. Starter diet was offered to them ad libitum from the age of 6 weeks (ČOS 2). After weaning the piglets were fed with feed mixture A1.

\section{Sampling and analyses}

Blood ( $2 \mathrm{ml})$ was collected from the minipigs on weeks 2, 4, 8, 13 and 17 from the cranial vena cava. EDTA (ethylenediaminetetraacetic acid) was used as anticoagulant for haematological examination.

Haematological examination included: haemoglobin concentration (Hb), packed cell volume (PCV), red blood cell count (RBC), mean corpuscular volume (MCV), mean corpuscular haemoglobin concentration (MCHC), mean corpuscular haemoglobin $(\mathrm{MCH})$, white blood cell count (WBC) and differential leukocyte count. Hb was measured photometrically using cyanomethaemoglobin method. PCV was measured using standard capillary tubes and centrifugation in a microhaematocrit centrifuge. RBC and (WBC) were determined in Bürker's chamber using Haym's and Türk's solution, respectively. MCV, MCH and MCHC were calculated. Blood smears for determination of differential leukocyte count were prepared and stained according to May-Grünwald and GiemsaRomanowski.

The minipigs were weighed (body weight - BW) on weeks 2, 4, 8, 13 and 17 of age.

Statistical analyses

The results were evaluated statistically by Student's $t$-test.

\section{Results}

The results are presented as mean values and standard deviations of each index. Values with $* P<0.05$ and $* * P<0.01$ express significant difference between group $\mathrm{H}$ and the two other groups (group A and group M). 


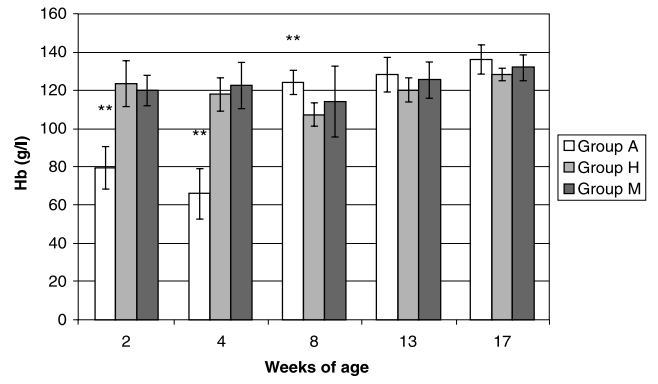

Fig. 1. Hemoglobin concentration $(\mathrm{Hb})$

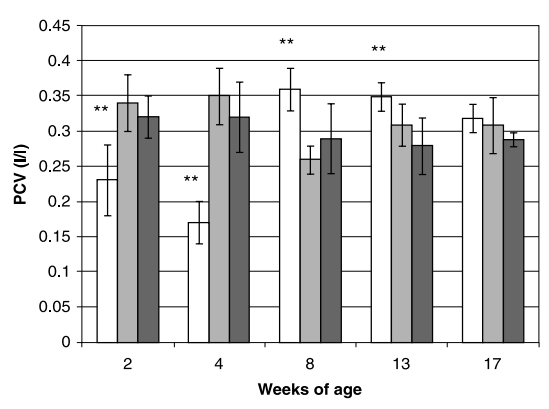

Fig. 2. Packed cell volume (PCV)

Haemoglobin concentration (Hb) (Fig. 1)

In melanoma-free $\mathrm{H}$ group of minipigs with early iron supplementation the maximum values of $\mathrm{Hb}$ were found 2 weeks after birth. From 2 to 8 weeks of age, $\mathrm{Hb}$ showed a decreasing tendency. Thereafter, $\mathrm{Hb}$ was steadily increasing till the end of the trial.

In melanoma-free A group of minipigs that were not supplemented with iron, significantly lower values of $\mathrm{Hb}$ were found at the age of $2(P<0.01)$ and 4 weeks $(P<0.01)$ compared to group $\mathrm{H}$. $\mathrm{Hb}$ in group A increased significantly after single i.m. injection of iron dextran (on week 5 of age). It was found to be even higher $(P<0.01)$ than in group $\mathrm{H}$ at week 8 of age. No statistically significant differences in $\mathrm{Hb}$ were found between group $\mathrm{H}$ and A starting from 13th week of age.

No differences in $\mathrm{Hb}$ between group $\mathrm{H}$ and $\mathrm{M}$ (early iron-supplemented melanomabearing minipigs) were found during the study.

Packed cell volume (PCV) (Fig. 2)

Development of PCV was similar to that of $\mathrm{Hb}$. At 2 and 4 weeks of age, PCV in group A was significantly lower compared to group $\mathrm{H}(P<0.01)$. From week 4 to week 8 of age, $\mathrm{PCV}$ in group $\mathrm{H}$ exhibited a decrease $(P<0.01)$. After administration of iron dextran (at the age of 5 weeks) in group A, PCV increased significantly and at 8 and 13 weeks of age it was even higher than in group $\mathrm{H}(P<0.01)$.

No differences in PCV between group $\mathrm{H}$ and $\mathrm{M}$ were found during the trial.

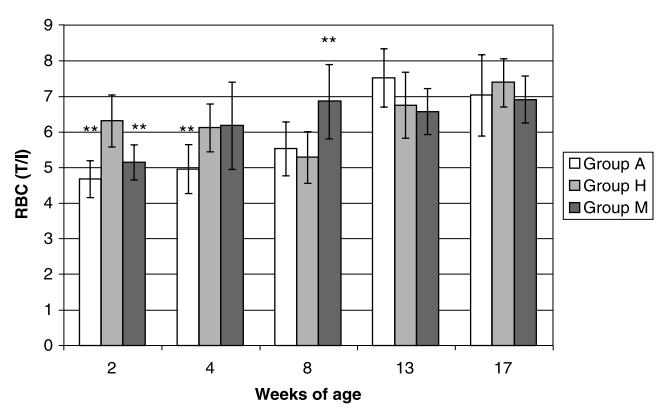

Fig. 3. Red blood cell count (RBC)

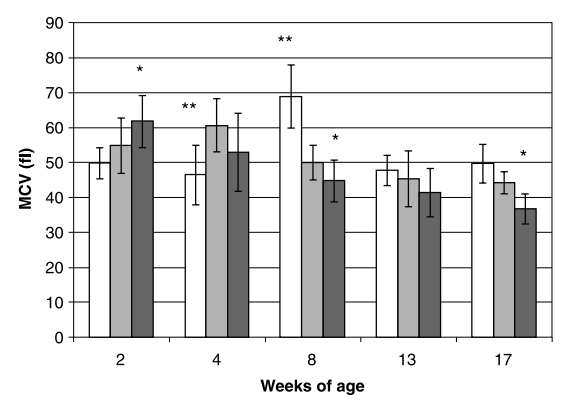

Fig. 4. MCV

Red blood cell count (RBC) (Fig. 3)

Significant differences between group $\mathrm{A}$ and $\mathrm{H}$ were found at 2 and 4 weeks of age, when $\mathrm{RBC}$ in group $\mathrm{H}$ was higher than in group $\mathrm{A}(\mathrm{P}<0.01)$. From the 2 nd to the 8 th week of age, $\mathrm{RBC}$ in group $\mathrm{H}$ showed decreasing tendency. After administration of iron dextran in group $\mathrm{A}$ (week 5 of age), RBC increased significantly. 
Table 1. White blood cell indices during the trial. Values with superscripts depict significant differences between the group $\mathrm{H}$ and the two other groups (group $\mathrm{A}$ and group $\mathrm{M}$ ) $* P<0.05$ and $* * P<0.01$

\begin{tabular}{|c|c|c|c|c|c|}
\hline Weeks of age & Index & Unit & $\begin{array}{c}\text { Group A } \\
\text { mean } \pm \text { SD }\end{array}$ & $\begin{array}{c}\text { Group H } \\
\text { mean } \pm \text { SD }\end{array}$ & $\begin{array}{c}\text { Group M } \\
\text { mean } \pm \text { SD }\end{array}$ \\
\hline \multirow{11}{*}{2} & WBC & $\mathrm{G} / 1$ & $11.17 \pm 5.61$ & $10.67 \pm 3.38$ & $12.29 \pm 5.04$ \\
\hline & \multirow{2}{*}{ Lymphocytes } & $\%$ & $77.09 \pm 8.39$ & $74.4 \pm 8.57$ & $74.59 \pm 12.04$ \\
\hline & & $\mathrm{G} / 1$ & $7.44 \pm 5.39$ & $7.94 \pm 2.87$ & $10.25 \pm 5.01$ \\
\hline & \multirow{2}{*}{ Monocytes } & $\%$ & $0.73 \pm 1.21$ & $1.40 \pm 1.20$ & $2.82 \pm 2.33$ \\
\hline & & $\mathrm{G} / 1$ & $0.06 \pm 0.14$ & $0.13 \pm 0.12$ & $0.41 \pm 0.40$ \\
\hline & \multirow{2}{*}{$\begin{array}{l}\text { Neutrophilic } \\
\text { granulocytes }\end{array}$} & $\%$ & $20.46 \pm 8.46$ & $16.40 \pm 8.57$ & $20.53 \pm 11.35$ \\
\hline & & $\mathrm{G} / 1$ & $1.95 \pm 0.90$ & $1.86 \pm 0.89$ & $1.93 \pm 1.20$ \\
\hline & \multirow{2}{*}{$\begin{array}{l}\text { Eosinophilic } \\
\text { granulocytes }\end{array}$} & $\%$ & $1.64 \pm 1.15 * *$ & $6.90 \pm 3.62$ & $1.71 \pm 3.16$ \\
\hline & & $\mathrm{G} / 1$ & $0.14 \pm 0.10 * *$ & $0.76 \pm 0.51$ & $0.26 \pm 0.50 * *$ \\
\hline & \multirow{2}{*}{$\begin{array}{l}\text { Basophilic } \\
\text { granulocytes }\end{array}$} & $\%$ & $0.09 \pm 0.29$ & $0.90 \pm 0.83$ & $0.47 \pm 0.70$ \\
\hline & & $\mathrm{G} / 1$ & $0.01 \pm 0.02$ & $0.08 \pm 0.07$ & $0.03 \pm 0.06$ \\
\hline \multirow{11}{*}{4} & WBC & $\mathrm{G} / 1$ & $13.47 \pm 5.97$ & $12.62 \pm 5.04$ & $10.10 \pm 2.93$ \\
\hline & \multirow{2}{*}{ Lymphocytes } & $\%$ & $76.55 \pm 7.23 * *$ & $67.89 \pm 5.38$ & $65.06 \pm 9.26$ \\
\hline & & $\mathrm{G} / 1$ & $10.34 \pm 4.56$ & $8.77 \pm 3.46$ & $7.02 \pm 2.40$ \\
\hline & \multirow{2}{*}{ Monocytes } & $\%$ & $0.82 \pm 1.59$ & $2.44 \pm 1.34$ & $3.00 \pm 1.53$ \\
\hline & & $\mathrm{G} / 1$ & $0.19 \pm 0.40$ & $0.36 \pm 0.29$ & $0.30 \pm 0.21$ \\
\hline & \multirow{2}{*}{$\begin{array}{l}\text { Neutrophilic } \\
\text { granulocytes }\end{array}$} & $\%$ & $21.55 \pm 6.96$ & $28.67 \pm 6.16$ & $30.82 \pm 9.04$ \\
\hline & & $\mathrm{G} / 1$ & $2.84 \pm 1.60$ & $3.49 \pm 1.28$ & $3.2 \pm 1.54$ \\
\hline & \multirow{2}{*}{$\begin{array}{l}\text { Eosinphilic } \\
\text { granulocytes }\end{array}$} & $\%$ & $0.27 \pm 0.45$ & $0.57 \pm 0.96$ & $0.88 \pm 1.49$ \\
\hline & & $\mathrm{G} / 1$ & $0.03 \pm 0.05$ & $0.06 \pm 0.07$ & $0.11 \pm 0.18$ \\
\hline & \multirow{2}{*}{$\begin{array}{l}\text { Basophilic } \\
\text { granulocytes }\end{array}$} & $\%$ & $0.36 \pm 0.48$ & $0.57 \pm 0.68$ & $0.24 \pm 0.73$ \\
\hline & & $\mathrm{G} / 1$ & $0.04 \pm 0.05$ & $0.05 \pm 0.08$ & $0.04 \pm 0.09$ \\
\hline \multirow{11}{*}{8} & WBC & $\mathrm{G} / 1$ & $20.18 \pm 4.95$ & $17.42 \pm 4.14$ & $17.20 \pm 5.42$ \\
\hline & \multirow{2}{*}{ Lymphocytes } & $\%$ & $68.00 \pm 7.73$ & $76.10 \pm 10.96$ & $63.18 \pm 9.40 * *$ \\
\hline & & $\mathrm{G} / \mathrm{L}$ & $13.59 \pm 3.09$ & $13.02 \pm 2.97$ & $10.92 \pm 3.25$ \\
\hline & \multirow{2}{*}{ Monocytes } & $\%$ & $2.27 \pm 1.14$ & $1.90 \pm 1.81$ & $2.53 \pm 1.75$ \\
\hline & & $\mathrm{G} / 1$ & $0.40 \pm 0.26$ & $0.35 \pm 0.35$ & $0.48 \pm 0.36$ \\
\hline & \multirow{2}{*}{$\begin{array}{l}\text { Neutrophilic } \\
\text { granulocytes }\end{array}$} & $\%$ & $29.36 \pm 6.36$ & $21.80 \pm 11.00$ & $33.35 \pm 8.18 *$ \\
\hline & & $\mathrm{G} / 1$ & $5.85 \pm 2.09$ & $4.01 \pm 2.70$ & $5.96 \pm 2.68$ \\
\hline & \multirow{2}{*}{$\begin{array}{l}\text { Eosinophilic } \\
\text { granulocytes }\end{array}$} & $\%$ & $0.73 \pm 1.97$ & $0.20 \pm 0.40$ & $0.94 \pm 1.35$ \\
\hline & & $\mathrm{G} / 1$ & $0.13 \pm 0.23$ & $0.04 \pm 0.08$ & $0.24 \pm 0.31$ \\
\hline & \multirow{2}{*}{$\begin{array}{l}\text { Basophilic } \\
\text { granulocytes }\end{array}$} & $\%$ & $0.18 \pm 0.39$ & $0.10 \pm 0.30$ & $0.35 \pm 0.59$ \\
\hline & & $\mathrm{G} / 1$ & $0.02 \pm 0.05$ & $0.01 \pm 0.04$ & $0.11 \pm 0.13$ \\
\hline & WBC & $\mathrm{G} / 1$ & $23.91 \pm 5.23$ & $21.33 \pm 5.39$ & $20.44 \pm 6.24$ \\
\hline & Lymphocytes & $\%$ & $67.00 \pm 8.93$ & $68.40 \pm 8.30$ & $68.12 \pm 9.56$ \\
\hline & Lympnocytes & $\mathrm{G} / 1$ & $15.24 \pm 2.96$ & $14.59 \pm 4.13$ & $14.91 \pm 5.82$ \\
\hline & Monocytes & $\%$ & $2,45 \pm 2.50$ & $1.90 \pm 2.07$ & $1.53 \pm 1.38$ \\
\hline & Monocyles & $\mathrm{G} / 1$ & $0.52 \pm 0.57$ & $0.47 \pm 0.35$ & $0.30 \pm 0.41$ \\
\hline 13 & Neutrophilic & $\%$ & $30.00 \pm 7.45$ & $26.20 \pm 7.92$ & $24.00 \pm 10.31$ \\
\hline & granulocytes & $\mathrm{G} / 1$ & $7.28 \pm 3.45$ & $5.65 \pm 2.31$ & $3.78 \pm 1.49$ \\
\hline & Eosinphilic & $\%$ & $1.45 \pm 1.97$ & $3.30 \pm 4.08$ & $5.59 \pm 6.62$ \\
\hline & granulocytes & $\mathrm{G} / 1$ & $0.19 \pm 0.25$ & $0.65 \pm 0.78$ & $1.71 \pm 1.63 * *$ \\
\hline & Basophilic & $\%$ & $0.00 \pm 0.00$ & $0.20 \pm 0.40$ & $0.41 \pm 0.60$ \\
\hline & granulocytes & $\mathrm{G} / 1$ & $0.00 \pm 0.00$ & $0.04 \pm 0.07$ & $0.14 \pm 0.18$ \\
\hline & WBC & $\mathrm{G} / 1$ & $17.85 \pm 4.25$ & $15.37 \pm 3.87$ & $17.07 \pm 4.10$ \\
\hline & Lymnhocytes & $\%$ & $64.27 \pm 10.84$ & $68.43 \pm 8.80$ & $59.78 \pm 12.00$ \\
\hline & Lympnocytes & $\mathrm{G} / \mathrm{L}$ & $9.95 \pm 4.19$ & $8.92 \pm 1.61$ & $10.71 \pm 3.30$ \\
\hline & Monocytes & $\%$ & $1.73 \pm 2.22$ & $1.14 \pm 0.83$ & $0.56 \pm 0.91$ \\
\hline & Monocytes & $\mathrm{G} / 1$ & $0.30 \pm 0.45$ & $0.13 \pm 0.11$ & $0.08 \pm 0.12$ \\
\hline 17 & Neutrophilic & $\%$ & $33.00 \pm 10.35$ & $28.00 \pm 6.89$ & $37.67 \pm 12.36$ \\
\hline & granulocytes & $\mathrm{G} / 1$ & $5.69 \pm 2.53$ & $3.96 \pm 1.24$ & $6.65 \pm 2.41 *$ \\
\hline & Eosinophilic & $\%$ & $1.00 \pm 1.95$ & $2.00 \pm 2.78$ & $1.67 \pm 2.62$ \\
\hline & granulocytes & $\mathrm{G} / 1$ & $0.06 \pm 0.00$ & $0.34 \pm 0.46$ & $0.36 \pm 0.58$ \\
\hline & Basophilic & $\%$ & $0.09 \pm 0.29$ & $0.00 \pm 0.00$ & $0.33 \pm 0.47$ \\
\hline & granulocytes & $\mathrm{G} / 1$ & $0.00 \pm 0.08$ & $0.00 \pm 0.00$ & $0.07 \pm 0.10$ \\
\hline
\end{tabular}




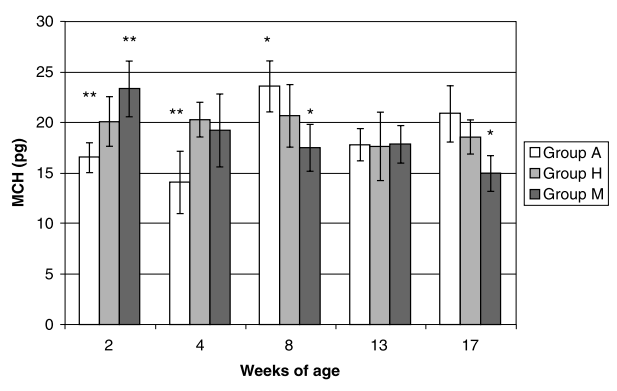

Fig. 5. $\mathrm{MCH}$

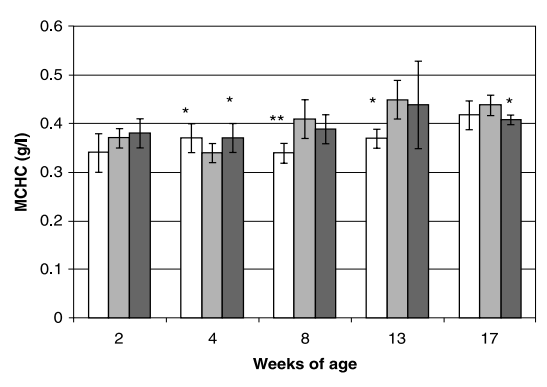

Fig. 6. MCHC

Statistically significant differences between groups $\mathrm{H}$ and $\mathrm{M}$ were found at 2 and 8 weeks of age. At 2 weeks of age, $\mathrm{RBC}$ in group $\mathrm{M}$ was lower than in group $\mathrm{H}(P<0.01)$. From week 2 of age, RBC in group $M$ exhibited an increasing tendency and at the age of 8 weeks it was even higher compared to group $\mathrm{H}(P<0.01)$.

MCV, MCH (Fig. 4, 5)

MCV and MCH in group A were significantly lower than in group $\mathrm{H}(\mathrm{P}<0.01)$ on week 4 of age. After application of iron dextran in group A (week 5 of age), MCV and $\mathrm{MCH}$ increased significantly and at the age of 8 weeks MCV $(\mathrm{P}<0.01)$ and $\mathrm{MCH}(\mathrm{P}<0.05)$ were even higher than in group $\mathrm{H}$.

Statistically significant differences between groups $\mathrm{H}$ and $\mathrm{M}$ were found on weeks 2, 8 and 17 of age. MCV $(\mathrm{P}<0.05)$ and $\mathrm{MCH}(\mathrm{P}<0.01)$ in group $\mathrm{M}$ was higher on week 2 of age. Lower MCV and $\mathrm{MCH}$ were found in group $\mathrm{M}(\mathrm{P}<0.05)$ on weeks 8 and 17 of age.

MCHC (Fig. 6)

MCHC in group A was higher at week 4 of age $(P<0.05)$ and lower at weeks $8(P<0.01)$ and weeks 13 of age $(P<0.05)$ compared to group $\mathrm{H}$.

On week 4 of age, MCHC in group M was higher $(P<0.05)$ and on week 17 of age it was lower $(P<0.05)$ than in group $\mathrm{M}$.

White blood cell indices (Table 1)

No statistically significant differences in total white blood cell count between group A and group $\mathrm{H}$ were found during the trial. Statistically significant differences between group $\mathrm{A}$ and group $\mathrm{H}$ were found at the age of 2 weeks in relative and absolute numbers of eosinophilic granulocytes (higher in group $\mathrm{H}, P<0.01$ ). At the age of 4 weeks, significant differences were found in relative numbers of lymphocytes (higher in group $\mathrm{A}, P<0.01$ ) and neutrophilic granulocytes (lower in group A, $P<0.05$ ).

No statistically significant differences in white blood cell count (WBC) between groups $\mathrm{H}$ and group $\mathrm{M}$ were found during the trial. At the age of 8 weeks, relative numbers of neutrophilic granulocytes in group $\mathrm{M}$ were higher $(P<0.05)$ and relative counts of lymphocytes were lower $(P<0.01)$ compared to group $\mathrm{H}$. In absolute leukocytes numbers, differences between group $\mathrm{M}$ and group $\mathrm{H}$ were found in eosinophilic granulocytes numbers at the age of 2 weeks (lower in group M, $P<0.01$ ) and at the age of 13 weeks (higher in group $\mathrm{M}, P<0.01)$. Absolute numbers of neutrophilic granulocytes in group $\mathrm{M}$ were higher compared to group $\mathrm{H}(P<0.05)$ at week 17 of age.

\section{Body weight (BW) (Fig. 7)}

No significant differences in BW between group $\mathrm{A}$ and group $\mathrm{H}$ were found during the trial. On the other hand, the animals in group M (bearing melanomas) achieved statistically significantly lower body weight than the animals in group $\mathrm{H}$ at the age of 13 and 17 weeks (both, $P<0.01$ ). 


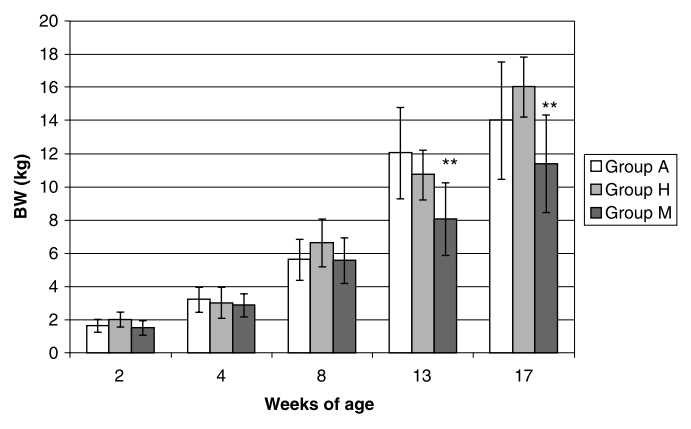

Fig. 7. Body weight (BW), ${ }^{*} P<0.05,{ }^{* *} P<0.01$

\section{Discussion}

Development of haematological indices in group $\mathrm{H}$

Development of haematological indices of healthy (melanoma-free), iron supplemented MeLiM minipigs were compared to literature data from various strains of minipigs. We have found similar development of PCV values as Gregor (1979) in the MINI-LEWE minipigs, i.e. a decrease of PCV between 4 and 8 weeks of age and an increase after the $8^{\text {th }}$ week of age. On the other hand,

Mandel and Trávníček (1982) reported different results with Minnesota minipigs. They found an increasing tendency of PCV from birth until 8 weeks of age. Tumbleson et al. (1972) and Buck (1975) found only non-significant oscillation in PCV values from birth to week 7 of age and their maximum values were not higher than 0.38 1/l. Similar results reported also Becker et al. (1976) and Wrogemann and Holtz (1977) in Göttingen minipigs. On the other hand, Perings et al. (1975) and Gleining (1969) reported values of PCV ranging from $0.42-0.491 / 1$. Changes of $\mathrm{Hb}$ values observed during the trial were similar to these of PCV.

Development of MCV, MCH, MCHC and RBC in our study was different from the study of Mandel and Trávníček (1982) conducted on Minnesota minipigs. While these authors found an increasing tendency of MCV, MCH, RBC and decreasing tendency of MCHC during the first 8 weeks of live, the development of these indices in the MeLiM minipigs was just the opposite. On the other hand, similar development of $\mathrm{MCV}, \mathrm{MCH}, \mathrm{MCHC}$ and $\mathrm{RBC}$ indices as in the MeLiM minipigs was found in the MINI-LEWE minipigs (Gregor 1979). These conflicting findings could be probably explained by testing various strains of minipigs at different experimental conditions.

The decrease of $\mathrm{Hb}, \mathrm{PCV}, \mathrm{MCV}, \mathrm{MCH}$ and $\mathrm{RBC}$ in group $\mathrm{H}$ indicates that iron reserves started to be depleted. After weaning (week 9 of age) all examined red blood cell indices increased significantly. This indicates that pigs started to receive iron from the feed mixture.

We have noted an increase of white blood cell count from 8 to 13 weeks of age. Most of the authors agree that leukocyte count increases at weaning and shortly thereafter (Wiebe 1968; Greg or 1979). This is probably caused by post-weaning stress and by colonization of intestinal tract by microbes from the outer environment (Mandel and Trávníček 1982). It is known that a prevalent proportion of leukocytes in pigs is formed by lymphocytes (Friendship and Henry 1992). It was also confirmed in our study. As to the other comparative data, development of eosinophilic granulocytes was similar to that reported by Gregor (1979) in the MINI-LEWE minipigs. The author found a decrease of eosinophilic granulocyte numbers between weeks 3 and 8 of age and their increasing tendency till the age of 20 weeks.

Development of haematological indices in group A

We found significantly lower values of $\mathrm{Hb}, \mathrm{PCV}, \mathrm{MCV}, \mathrm{MCHC}$ and $\mathrm{RBC}$ in group $\mathrm{A}$ of melanoma-free MeLiM minipigs in which the animals were not supplemented with iron till week 5 of age compared to early iron supplemented groups $\mathrm{H}$ and $\mathrm{M}$. The red blood cell picture was characteristic of hypochromic microcytary anaemia. The MeLiM minipigs of group A were treated with i.m. application of $100 \mathrm{mg} \mathrm{Fe}^{3+}$ in the form of iron dextran at week 5 of age. This resulted in a dramatic increase of $\mathrm{Hb}, \mathrm{PCV}, \mathrm{MCV}, \mathrm{MCH}$ and $\mathrm{RBC}$ and these indices were at the age of 8 weeks even higher than in early iron supplemented groups. A rise in MCV indicates production of new erythrocytes with greater number of large immature cells released into the circulation (Holter et al. 1991). 
As to the development of $\mathrm{Hb}, \mathrm{PCV}, \mathrm{MCV}$ and $\mathrm{MCH}$ in group $\mathrm{A}$, we have found that it was similar to the development that is known in commercial breeds of pigs (Svoboda and Drábek 2002). The only difference was found in the development of RBC. While the RBC has a decreasing tendency in anaemic piglets of commercial breed (S voboda and Drábek 2002), the RBC in MeLiM minipigs (even though it was lower than in group H) remained at approximately the same level during the first 4 weeks of life. We suggest that it could be explained by lower growth intensity of minipigs. It is known that piglets of commercial breeds have a high growth rate after birth. During the first week, the piglet doubles its body mass from 1.5 to $3 \mathrm{~kg}$. At the same time the plasma volume expands by $30 \%$ (Jain 1986 ; Thorn 2000). The expansion of plasma volume is not compensated by production of new erythrocytes during iron deficiency. In minipigs, the growth intensity is much lower, that is why the RBC remained on the same level.

No differences between anaemic and healthy piglets were found in total leukocyte count. Our findings are not in agreement with results of Egeli et al (1998) and Gainer and Guarnieri (1985) who found that anaemic piglets of commercial breeds had lower leukocyte count than the healthy ones. We found that anaemic MeLiM minipigs had lower relative and actual numbers of eosinophils and lower relative numbers of neutrophils. This corresponds with the findings of Egeli et al. (1998) and Gainer and Guarnieri (1985) in commercial breeds of pigs.

In our study no statistically significant differences in body weights between anaemic and healthy minipigs were found. On the contrary, in piglets of commercial breeds, the iron deficiency has a detrimental effect on growth intensity starting from 2 weeks of age (Svoboda and Drábek 2002). This discrepancy could be explained again by the fact that the growth intensity of minipigs is much lower compared to commercial breeds of pigs. Therefore the impact of iron deficiency on growth intensity of minipigs can not be demonstrated in such a degree as in commercial breed piglets.

Development of haematological indices in group $\mathrm{M}$

Cancer patients frequently develop anaemia. In association with malignant melanoma in human patients, decreased procoagulation activity was found (Siddiqui and Francis 2001). Another impact of malignant melanoma is bleeding from intestinal metastasis (Wong et al. 1999). According to Kovar et al. (1997) tumour cells have high demand for iron. Displacement of normal bone marrow by tumour cells (Kettelhack et al. 1994) and increased retention of transferrin in tumour tissue (Aulbert 1989a, b) can also contribute to anaemia development in cancer patients.

However, no statistically significant differences in red blood cell indices, with exception of $\mathrm{RBC}$, were found between groups $\mathrm{M}$ and $\mathrm{H}$. In melanoma-bearing group of the MeLiM minipigs (group M) we have found increasing tendency of RBC and at week 8 of age it was even higher than in $\mathrm{H}$ group of healthy piglets. This indicates an increased erythropoiesis in melanoma affected minipigs. This is contradictory to findings of Kettelh ack et al. (1994) reported from human patients with solid tumours. Although the authors reported that serum erythropoietin (EPO) was clearly elevated in anaemic tumour patients, the levels of EPO in tumour patients without anaemia were decreased. They also suggest that the turnover of EPO is increased in malignant disease with a negative effect on erythropoiesis. Further studies are desirable to clarify our finding in melanoma affected minipigs.

\section{Vývoj hematologických ukazatelů u linie miniprasat MeLiM}

Cílem práce bylo zjistit vývoj hematologických ukazatelů u miniaturních prasat linie MeLiM. Miniprasata ve skupině M byla postižena dědičným maligním melanomem. Těmto prasatům byl 3. den života aplikován dextran železa (100 $\left.\mathrm{mg} \mathrm{Fe}^{3+}\right)$ i.m. Ve skupině H byla kontrolní miniprasata bez melanomu, kterým bylo aplikováno železo stejným způsobem 
jako u skupiny M. Skupina A zahrnovala miniprasata bez melanomu, kterým bylo aplikováno železo až ve stáří 5 týdnů. Vývoj hematologických hodnot ve skupině H byl porovnán s literárními údaji zjištěnými u jiných plemen a linií miniprasat. Hodnoty ukazatelů červeného krevního obrazu ve skupině A byly charakteristické pro hypochromní mikrocytární anémii. Ve skupině zvířat postižených melanonem byly ve věku 8 týdnů zjištěny vyšší počty erytrocytů ve srovnání se skupinou H. Prasata ve skupině M vykazovala ve srovnání se skupinou $\mathrm{H}$ nižší intenzitu růstu.

\section{Acknowledgement}

The authors thank Mrs. Miluše Hokešová and Mrs. Jaroslava Šestáková for technical assistance. This work was supported by the Czech Science Foundation (grant No. 524/01/0162) and by the Academy of Sciences of the Czech Republic (grant No. S5045113).

Supported by the project MSM 6215712403

\section{References}

AULBERT E 1989a: Die Anämie bei malignen Tumorerkrankungen. I. Tumorbedingte Verluste von Transferrin und ihre Abhängigkeit von Tumorgrösse und Malignitätsgrad am Modell der Ratte. Nucl Med 28: $193-200$

AULBERT E 1989b: Die Anämie bei malignen Tumorerkrankungen. II. Tumorbedingte Verluste von Transferrin als Ursache für die Entwicklung einer Anämie am Modell der Ratte. Nucl Med 28: 247-254

BECKER M, BERLINGER R, STAUFER UG 1976: Das Göttinger Miniaturschwein als Versuchstier. 2. Mittlg. Bultbild, Serumelektrolyte, Wasserstoffionenkonzentration und Blutgase. Res Exp Med 167: 185-192

BOROVANSKÝ J, HORÁK V, ELLEDER M, FORTÝN K, SMIT NPM, KOLB AM 2003: Biochemical characterization of a new melanoma model - the minipig MeLiM strain. Melanoma Res 13: 543-548

BUCK WH 1975: Hämatologische und immunologische Untersuchungen an Ferkeln. Diss, Univ. Stuttgart

CARLSSON H, LINDVALL S, THAFVELIN B 1974: Properties of a complex of iron and a sorbitol-gluconic acid polymer for treatment of piglet anaemia. Acta Vet Scand 15: 100-110

CSAPÓ JE 1995: Protein, fats, vitamins and mineral concentration in porcine colostrum and milk from parturion to 60 days. Int Dair J 6: $881-902$

EGELI AK, FRAMSTAD T, MORBERG H 1998: Clinical biochemistry, haematology and body weight in piglets. Acta Vet Scand 39: 381-393

FORTÝN K, HRUBAN V, HORÁK V 1994: Treatment of malignant melanoma. Br J Surg 81: 146-147

FORTÝN K, HRUBAN V, HORÁK V, TICHÝ J 1998: Exceptional occurence and extent of malignant melanoma in pig. Vet Med Czech 43: 87-91

FRAMSTAD T, SJAASTAD OV 1991: Iron supplementation in piglets. Norsk Veterinaertidsskrift 103: 21-27

FRIENDSHIP RM, HENRY BJ 1992: Cardiovascular System, Hematology and Clinical Chemistry. In Diseases of Swine, $7^{\text {th }}$ ed., eds. A. D. Leman et al., Iowa State University Press, Ames, Iowa, p. 6.

GAINER JH. GUARNIERI J 1985: Effects of poly I: C in porcine iron deficient neutropenia. Cornell Vet 75 : 454-465

GLEINIG D 1969: Untersuchungen über den Serumeisengehalt, den Plasmacalciumgehalt und den Hämatokritwert Vietnamesischer Hängebauchschweine. Diss, Univ. Hannover

GREGOR G 1979: Hämatologische und biochemische Untersuchungen am Miniaturschwein MINI-LEWE. Z. Versuchstierk 21: 92-106

HOLTER PH, FRAMSTAD T, AULIE A, REFSUM HE, SJAASTAD OV 1991: Effect on iron treatment on erytrocyte parameters in postnatal anaemia of the pig. Pediat Haematol Oncol 8: 1-11

HORÁK V, FORTÝN K, HRUBAN V, KLAUDY J 1999: Hereditary melanoblastoma in miniature pigs and its successful therapy by devitalization technique. Cell Mol Biol 45: 1119-1129

HRUBAN V, HORAK V, FORTYN K, HRADECKY J, KLAUDY J, SMITH DM, REISNEROVA H, MAJZLIK I 2004: Inheritance of malignant melanoma in the MeLiM strain of miniature pigs. Vet Med-Czech 49: 453-459

JAIN, NC 1986: Shalm's Veterinary Haematology, 4th ed, pp. 240-255

KETTELHACK C, SCHOTER D, MATTHIAS D, SCHLAG PM 1994: Serum erythropoietin levels in patients with solid tumors. Eur J Cancer 30 A: 1289-1291

KLEINBECK S, MCGLONE J 1999: Intensive indole versus outdoor production systeme: Genotype and supplemental iron effects on blood hemoglobin and selected immune measures in zouny pigs. J Anim Sci 77: 2384-2390

KOVAR J, STUNZ LL, STEWART BC, KRIEGERBECKOVA K, ASHMAN RF, KEMP JD 1997: Direct evidence that iron deprivation induces apoptosis in murine lymphoma 38C13. Pathobiology 65: 61-68

MANDEL L, TRÁVNÍČEK J 1982: Haematology of conventional and germfree miniature Minnesota piglets. Z Versuchstierk 24: 299-307 
PERINGS E, HAUSWALD CH, SCHUMANN E, SEIDENKRANZ HG, SMIDT D, HOLTZ W, MAYER JN 1975: Untersuchungen zum Einfluß von Azathioprin aus das periphere Blutbild und blutbildende Organe bei Göttinger Miniaturschweinen. Dtsch tierärztl Wschr 82: 281-285

POHLREICH P, STŘÍBRNÁ J, KLEIBL Z, HORÁK V, KLAUDY J 2001: Detection of neoplastic cells in blood of miniature pigs with hereditary melanoma. Vet-Med Czech 46: 199-204

SIDDIQUI FA, FRANCIS JL 2001: Hemoglobin binds melanoma cell tissue factor and enhances its procoagulant activity. Blood Coagul Fibrinolysis 12: 171-177

SVOBODA M, DRÁBEK J 2002: Effect of oral administration of $\mathrm{Fe}^{2+}$-fumarate on erythrocyte profile and growth rate of suckling piglets. Acta Vet Brno 71: 217-222

THORN CE 2000: Shalm's Veterinary Haematology, 5th ed, pp. 1089-1095

TUMBLESON ME, BADGER TM, BAYKER PC, HUTCHESON DP 1972: Systematic oscillation of serum biochemie and hematologic parameters in sinclair miniature swine. J Anim Sci 35: 48

YU IT, LIN J, WU JF, YEN HT, LEE SL, YANG TS 2002: Reevaluation of the necessity of iron injection to newborn piglets. As-Aus J Anim Sci 15: 79-83

VENN J, MCCANCE R A, WIDDOWSON EM 1947: Iron metabolism in piglet anemia. J Comp Path 57: 314-325

VINCENT-NAULLEAU S, LE CHALONY C, LEPLAT J-J, BOUET S, BAILLY C, SPATZ A, VIELH P, AVRIL M-F, TRICAUD Y, GRUAND J, HORAK V, FRELAT G, GEFFROTIN C 2004: Clinical and histopathological characterization of cutaneous melanomas in the Melanoblastoma-bearing Libechov minipig model. Pigment Cell Res 17: 24-35

WIEBE G 1968: Hämatologische Untersuchungen bei Vietnamesischen Hängebauchschweinen. Diss, Hannover

WONG LS, BOUGHLI I, ODOGWU S, ROBERTS PN 1999: Metastatic melanoma of the small bowel as a cause of occult intestinal bleeding. Exp Hematol 27: 806-810.

WROGEMANN J, HOLTZ W 1977: Blutuntersuchungen am Göttinger Miniaturschwein. Z Versuchstierk 19: 276-289

ZIMMERMANN W 1995: Auswirkungen diverser Anämieprophylaxeformen auf die Blutparameter der Saugferkel. Dtsch Tierärztl Wschr 102: 32-38 
